\title{
LIKUIDITAS, LEVERAGE, PROFITABILITAS PENGARUHNYATERHADAP NILAI PERUSAHAAN MANUFAKTUR DI INDONESIA MELALUI KEBIJAKAN DEVIDEN
}

\author{
Ainun Jariah \\ Program Studi Manajemen, STIE Widya Gama Lumajang \\ anjar040820@gmail.com
}

\begin{abstract}
The company's value can be found on the ability to pay dividends. The amount of dividends paid to shareholders depend on the dividend policy of each company. This study aims to determine how the effect of liquidity, leverage, profitability toward dividend policy and the value of manufacturing companies in Indonesia. The number of samples are 8 manufacturing company. Data were analyzed using path analysis model. The results showed that liquidity, leverage, profitability have significantly influence on the company's value, through the variable dividend policy shows the effect of the narrowing means that the value of the company was affected by the dividend policy is not significant. Partially, not all variables have a significant effect, just variables liquidity and leverage have correlation coefficient $(R)$ of 0.574 with a significance of 0.025 which means proven strong correlation with the criteria. While the value of the coefficient of determination ( $R$ square) is $32.9 \%$, which variables liquidity, leverage, profitability have influence to company's value.
\end{abstract}

Keywords: Liquidity, Leverage , Profitability, Dividend Policy, Values of Firm.

\section{Pendahuluan}

Nilai perusahaan dapat menyejahterakan pemegang saham secara maksimum apabila harga saham meningkat. Semakin tinggi harga saham sebuah perusahaan, maka makin tinggi kesejahteraan pemegang saham. Enterprise Value (EV) atau dikenal juga sebagai firm value (nilai perusahaan) merupakan konsep penting bagi investor, karena merupakan indikator bagi pasar menilai perusahaan secara keseluruhan (Nurlela dan Ishaluddin, 2008 dalam Kusumadilaga, 2010). Wahyudi, Nurlela dan Ishaluddin (2008) dalam Kusumadilaga (2010) menyebutkan bahwa nilai perusahaan merupakan harga yang bersedia dibayar oleh calon pembeli jika perusahaan tersebut dijual. Nilai perusahaan merupakan cerminan dari penambahan dari jumlah ekuitas perusahaan dengan hutang perusahaan. Ada beberapa faktor yang mempengaruhi nilai perusahaan, yaitu : keputusan pendanaan, kebijakan dividen, keputusan investasi, struktur modal, pertumbuhan perusahaan, ukuran perusahaan. Beberapa faktor tersebut memiliki hubungan dan pengaruh terhadap nilai perusahaan yang tidak konsisten. Nilai perusahaan adalah nilai laba masa yang akan datang di ekspektasi yang dihitung kembali dengan suku bunga yang tepat (Winardi, 2001 dalam Kusumadilaga, 2010).

Sebelum seorang investor akan memutuskan akan menginvestasikan dananya di pasar modal (dengan membeli sekuritas yang diperdagangkan di bursa) ada kegiatan terpenting yang perlu untuk dilakukan, yaitu penilaian dengan cermat terhadap emiten, ia harus percaya bahwa informasi yang diterimanya adalah informasi yang benar. Tanpa keyakinan tersebut, pemodal tentunya tidak akan bersedia membeli sekuritas yang ditawarkan perusahaan (atau diperjual-belikan di bursa). Indikator kepercayaan pemodal akan pasar modal dan instrumen-instrumen keuangannya, dicerminkan antara lain oleh dana masyarakat yang dihimpun di pasar modal (Pinuji, 2009).

Kinerja keuangan perusahaan merupakan salah satu faktor yang dilihat oleh calon investor untuk menentukan investasi saham. Bagi sebuah perusahaan, menjaga dan meningkatkan kinerja keuangan adalah suatu keharusan agar saham tersebut tetap eksis dan tetap diminati oleh investor. Laporan keuangan yang diterbitkan perusahaan merupakan cerminan dari kinerja keuangan perusahaan. Para pelaku pasar modal seringkali menggunakan 
informasi tersebut sebagai tolak-ukur atau pedoman dalam melakukan transaksi jual-beli saham suatu perusahaan.

Pengukuran kinerja perusahaan merupakan salah satu indikator yang dipergunakan oleh investor untuk menilai suatu perusahaan. Semakin baik kinerja perusahaan maka akan semakin tinggi return yang akan diperoleh oleh investor. Perolehan modal perusahaan dan nilai perusahaan akan meningkat apabila perusahaan memiliki reputasi baik yang tercermin dalam laporan keuangannya. Horne (2005) menyatakan bahwa (pengukuran kinerja keuangan meliputi hasil perhitungan rasio-rasio keuangan yang berbasis pada laporan keuangan perusahaan yang dipublikasikan dan telah di audit akuntan publik).

Analis atau investor akan menghitung rasiorasio keuangannya yang mencakup rasio likuiditas, leverage, aktivitas dan profitabilitas perusahaan untuk dasar pertimbangan dalam keputusan investasi. Dalam penelitian ini menggunakan rasio likuiditas, leverage dan profitabilitas (Riyanto, 2001).

Likuiditas menggambarkan kemampuan suatu perusahaan untuk memenuhi kewajiban finansialnya yang segera harus dipenuhi. Likuiditas akan mempengaruhi besar kecilnya dividen yang dibayarkan kepada para pemegang saham. (Dividen merupakan arus kas keluar, semakin besar jumlah kas yang tersedia maka dianggap baik likuiditas perusahaan, dan semakin besar pula kemampuan perusahaan untuk membayar dividen) (Harjito dan Martono, 2001). Penelitian ini menggunakan rasio likuiditas yang diwakili oleh cash ratio (CR) yaitu rasio yang menggambarkan kemampuan perusahaan untuk membayar utang yang harus dipenuhi dengan kas yang tersedia dalam perusahaan.

Profitabilitas mengukur kemampuan perusahaan untuk menghasilkan laba. Rasio profitabilitas dalam penelitian ini diwakili oleh return on equity (ROE). ROE merupakan rasio yang menunjukkan tingkat pengembalian yang diperoleh pemilik atau pemegang saham atas investasi di perusahaan. ROE membandingkan besarnya laba bersih terhadap ekuitas saham biasa. Semakin tinggi ROE menunjukkan bahwa semakin tinggi tingkat pengembalian terhadap investasi yang dilakukan dan semakin rendah ROE suatu perusahaan maka tingkat pengembaliannya akan semakin rendah pula.

Leverage mengukur kemampuan perusahaan untuk memenuhi seluruh kewajiban finansialnya yang terdiri dari utang jangka pendek dan utang jangka panjangnya. Leverage dalam penelitian ini diwakili oleh debt to equity ratio (DER). DER merupakan rasio yang membandingkan total utang ekuitas. Rasio ini mengukur persentase dari dana yang diberikan oleh para kreditur. Total utang meliputi kewajiban lancar dan kewajiban jangka panjang. DER mencerminkan kemampuan perusahaan untuk membayar atau memenuhi kewajibannya dengan modal sendiri. DER menunjukkan hubungan antara jumlah pinjaman yang diberikan oleh pemilik perusahaan. Semakin besar rasio ini menunjukkan bahwa semakin besar struktur modal yang berasal dari utang digunakan untuk mendanai ekuitas yang ada, seperti yang dikemukakan oleh Warren et al. (2004) dalam Sitepu (2010) bahwa (semakin kecil rasio DER, semakin baik kemampuan perusahaan untuk dapat bertahan dalam kondisi yang buruk). Rasio DER yang kecil menunjukkan bahwa perusahaan masih mampu memenuhi kewajibannya kepada kreditur.

Nilai perusahaan dapat dilihat dari kemampuan perusahaan membayar dividen. Dividen adalah proporsi laba yang dibagikan kepada para pemegang saham dalam jumlah yang sebanding dengan jumlah lembar saham yang dimiliknya (Sunariyah, 2004). Ada saatnya dividen tersebut tidak dibagikan oleh perusahaan karena perusahaan merasa perlu untuk menginvestasikan kembali laba yang diperolehnya. Besarnya dividen tersebut dapat mempengaruhi harga saham. Apabila dividen yang dibayar tinggi, maka harga saham cenderung tinggi sehingga nilai perusahaan juga tinggi dan jika dividen dibayarkan kepada pemegang saham kecil maka harga saham perusahaan yang membagikannya tersebut juga rendah. Kemampuan sebuah perusahaan membayar dividen erat hubungannya dengan kemampuan perusahaan memperoleh laba. Jika perusahaan memperoleh laba yang tinggi, maka kemampuan perusahaan akan membayarkan dividen juga tinggi. Dengan dividen yang besar akan meningkatkan nilai perusahaan (Harjito dan Martono, 2005).

Besar Kecilnya dividen yang dibayarkan kepada pemegang saham tergantung pada kebijakan dividen masing-masing perusahaan dan dilakukan berdasarkan pertimbangan berbagai faktor. Menurut Gitman (2003) faktor-faktor yang mempengaruhi kebijakan dividen suatu perusahaan adalah debt 
covenant, likuiditas, posisi kas, prospek pertumbuhan perusahaan dan kuasa kendali para pemegang saham yang memiliki mayoritas saham perusahaan. Kebijakan dividen sebagai variabel intervening pengaruh kinerja keuangan terhadap nilai perusahaan, hal ini dikarenakan kebijakan dividen menjadi pusat perhatian banyak pihak seperti pemegang saham, kreditor, maupun pihak eksternal lain yang memiliki kepentingan dari informasi yang dikeluarkan perusahaan (Kartika, 2005 dalam Erlangga, 2009). kebijakan dividen mungkin memberi kontribusi terhadap pemahaman mengenai mengapa perusahaan membayar dividen kas.

Berdasarkan fenomena ini, maka penelitian ini meneliti mengenai pengaruh likuiditas, leverage, profitabilitas terhadap nilai perusahaan melalui kebijakan dividen. Adapun perumusan masalah sebagai berikut :

a. Apakah terdapat pengaruh likuiditas, leverage, profitabilitas yang signifikan secara parsial terhadap nilai perusahaan manufaktur di Indonesia?

b. Apakah terdapat pengaruh likuiditas, leverage, profitabilitas yang signifikan secara simultan terhadap nilai perusahaan manufaktur di Indonesia?

c. Apakah terdapat pengaruh likuiditas, leverage, profitabilitas yang signifikan secara simultan melalui variabel kebijakan dividen terhadap nilai perusahaan manufaktur di Indonesia?

d. Apakah terdapat hubungan likuiditas, leverage, profitabilitas yang signifikan secara parsial terhadap nilai perusahaan manufaktur di Indonesia?

e. Apakah terdapat hubungan likuiditas, leverage, profitabilitas yang signifikan secara simultan terhadap nilai perusahaan manufaktur di Indonesia?

f. Apakah terdapat hubungan antara kebijakan dividen yang signifikan terhadap nilai perusahaan manufaktur di Indonesia?

Penelitian ini bertujuan untuk mendapatkan bukti mengenai pengaruh likuiditas, leverage, profitabilitas terhadap nilai perusahaan melalui kebijakan dividen. Dan hasil penelitian ini diharapkan dapat memberikan manfaat atau kontribusi yang positif mengenai faktor-faktor yang dapat berpengaruh terhadap pengukuran nilai perusahaan.

\section{Kajian Pustaka dan Pengembangan Hipotesis}

Nilai Perusahaan

Nilai perusahaan akan tercermin dari harga sahamnya. Harga pasar dari saham perusahaan yang terbentuk antara pembeli dan penjual disaat terjadi transaksi disebut nilai pasar perusahaan, karena harga pasar saham dianggap cerminan dari nilai aset perusahaan sesungguhnya. Nilai perusahaan yang dibentuk melalui indikator nilai pasar saham sangat dipengaruhi oleh peluang-peluang investasi. Adanya peluang investasi dapat memberikan sinyal positif tentang pertumbuhan perusahaan dimasa yang akan datang, sehingga dapat meningkatkan nilai perusahaan (Untung, dkk, 2006 dalam Susanti, 2010).

Nilai perusahaan dalam penelitian ini didefinisikan sebagai nilai pasar, seperti halnya penelitian yang pernah dilakukan oleh Nurlela dan Islahudin (2008) dalam Kusumadilaga (2010). Karena nilai perusahaan dapat memberikan kemakmuran pemegang saham secara maksimum apabila harga saham perusahaan meningkat. Semakin tinggi harga saham, maka makin tinggi kemakmuran pemegang saham, untuk mencapai nilai perusahaan umumnya para pemodal menyerahkan pengelolaannya kepada para professional. Para professional diposisikan sebagai manajer ataupun komisaris (Nurlela dan Islahuddin, 2008 dalam Kusumadilaga, 2010).

Susanti (2010), Indikator- indikator yang mempengaruhi nilai perusahaan diantaranya adalah:

a. PER (Price Earning Ratio) yaitu rasio yang mengukur seberapa besar perbandingan antara harga saham perusahaan dengan keuntungan yang diperoleh para pemegang saham (Mohammad Usman, 2001 dalam Malla Bahagia, 2008). Rumus yang digunakan adalah :

$$
P E R=\frac{\text { Harga Pasar Saham }}{\text { Laba perLembarSaham }} x 100 \%
$$

Faktor-faktor

Yang

Mempengaruhi PER :

1) Tingkat pertumbuhan laba

2) Dividend Payout Ratio

3) Tingkat keuntungan yang disyaratkan oleh pemodal.

b. PBV (Price Book Value) 
Rasio ini mengukur nilai yang diberikan pasar keuangan kepada manajemen dan organisasi perusahaan sebagai sebuah perusahaan yang terus tumbuh (Brigham, 2006)., yang diproksikan dengan :

$$
P B V=\frac{\text { Nilai Pasar }}{\text { Harga Saham }} \times 100 \%
$$

Dalam penelitian ini nilai perusahaan diproksikan dengan Price earning Ratio.

\section{Likuiditas}

Likuiditas, yaitu rasio yang memberikan informasi tentang tingkat kemampuan perusahaan dalam membayar hutang-hutang jangka pendek. Likuiditas suatu perusahaan tergantung pada kemampuan untuk merubah aktiva non kas menjadi kas. Rasio ini terdiri dari rasio lancar (current ratio) dan rasio cepat (quick ratio).

James O. Gill dalam Kasmir (2008:130) menyebutkan "Rasio likuiditas mengukur jumlah kas atau jumlah investasi yang dapat dikonversikan atau diubah menjadi kas untuk membayar pengeluaran, tagihan, dan seluruh kewajiban lainnya yang sudah jatuh tempo".

Likuiditas sangat berhubungan dengan nilai perusahaan, semakin tinggi likuiditas perusahaan, maka semakin tinggi pula nilai perusahaan. Artinya likuiditas berpengaruh pisitif terhadap nilai perusahaan.

$$
\text { current ratio }=\frac{\text { current assets }}{\text { current liabilities }}
$$

\section{Leverage}

Fahmi (2014:75) rasio leverage adalah "Mengukur seberapa besar perusahaan dibiayai dengan utang". Penggunaan hutang yang terlalu tinggi akan membahayakan perusahaan karena perusahaan akan masuk dalam kategori extreme leverage (hutang ekstrime) yaitu perusahaan terjebak dalam tingkat hutang yang tinggi dan sulit untuk melepaskan beban hutang tersebut. Karena itu sebaiknya perusahaan harus menyeimbangkan beberapa hutang yang layak diambil dan dari mana sumber-sumber yang dapat dipakai untuk membayar hutang. Sartono (2010:120) "Rasio Leverage (solvabilitas) menunjukkan proporsi atas penggunaan utang untuk membiayai investasinya".

\section{Riset Akuntansi dan Keuangan Indonesia, 1(2), 2016}

Semakin tinggi leverage maka nilai perusahaan akan menurun juga, artinya leverage berpengaruh secara negatif terhadap nilai perusahaan.

\section{Profitabilitas}

Rasio ini mengukur efektivitas manajemen secara keseluruhan yang ditujukan oleh besar kecilnya tingkat keuntungan yang diperoleh dalam hubungannya dengan penjualan dan investasi. Semakin baik rasio profitabilitas maka semakin baik menggambarkan kemampuan tingginya perolehan keuntungan perusahaan. Harmono (2011:109) merupakan "Gambaran kinerja fundamental perusahaan ditinjau dari tingkat efisiensi dan efektivitas operasi perusahaan dalam memperoleh laba". Pengertian lain tentang rasio profitabilitas yakni menurut Sartono (2011:122) adalah "Kemampuan perusahaan memperoleh laba dalam hubungannya dengan penjualan, total aktiva maupun modal sendiri".

Semakin baik rasio profitabilitas maka menunjukkan kemampuan yang tinggi dalam memperoleh keuntungan dan semakin tinggi pula nilai perusahaan.

\section{Dividen}

Kebijakan dividen adalah kebijakan yang menyangkut tentang penggunaan laba yang menjadi hak para pemegang saham. Pada dasarnya laba tersebut bisa dibagi sebagai Dividen atau ditahan untuk diinvestasikan kembali. Perusahaan bisa membagi Dividen dalam bentuk uang tunai atau dalam bentuk saham (stock Dividen). Kebijakan dividen masih merupakan masalah yang mengundang perdebatan karena ada beberapa pendapat mengenai Dividen. Pertama, pendapat yang mengatakan dividen dibagi sebesar-besarnya (dividend relevant); Kedua, kebijakan dividen tidak relevan; dan ketiga perusahaan membagi dividen sekecil mungkin.

Jika perusahaan mampu meningkatkan pembayaran dividen karena peningkatan laba, maka harga saham akan naik.

\section{Metode Penelitian}

Penelitian ini termasuk jenis penelitian survei (survey research) yaitu penelitian yang tidak melakukan perubahan atau tidak ada perlakuan khusus terhadap variabel-variabel yang diteliti (non 
experimental). Tujuan penelitian ini bersifat eksplanatori (explanatory research) dimana penelitian eksplanatori merupakan jenis penelitian yang menjelaskan hubungan kausal antara satu variabel dengan variabel lainnya melalui pengujian hipotesis.

Penelitian ini dilakukan terhadap perusahaan manufaktur sektor industri barang konsumsi sub sektor food and beverages yang terdaftar di Bursa Efek Indonesia periode 2011 - 2014. Alasan dipilihnya perusahaan manufaktur yang listed di Bursa Efek Indonesia sebagai lokasi penelitian karena perusahaan tersebut adalah perusahaan terbuka sehingga peneliti lebih mudah untuk memperoleh data keuangan yang diperlukan.

Populasi dalam penelitian ini adalah perusahaan manufakturt yang listed di Bursa Efek Indonesia, periode 2011 - 2014, jadi keseluruhan berjumlah 70. Pengambilan sampel dilakukan dengan metode purposive sampling.

Teknik pengumpulan data menggunakan teknik observasi tidak langsung yaitu teknik dokumenter dimana data diperoleh dari catatan peristiwa yang sudah berlalu. Teknik dokumentasi digunakan dengan tipe pooled data yang dimaksudkan agar jumlah observasi memenuhi syarat pengujian OLS (Ordinary Least Square). Data yang diperoleh dilakukan evalusi dengan cara cross sectional approach dan time-series analysis.

\section{Nilai Perusahaan}

Nilai perusahaan menggunakan Price Earning Ratio (PER). Rumus yang digunakan adalah:

$$
\text { PER }=\frac{\text { Harga Pasar Saham }}{\text { Laba per LembarSaham }} \times 100 \%
$$

\section{Likuiditas}

Likuiditas dalam penelitian ini diproksikan dengan current ratio, Rumus untuk mencari rasio lancar atau current ratio sebagai berikut:

\section{Leverage}

Leverage akan diproksikan dengan debt to equity ratio, rumus untuk mencari rasio leverage adalah sebagai berikut:

debt to equity ratio $=\frac{\text { total liabilities }}{\text { total shareholder's equity }}$

\section{Profitabilitas}

Rasio profitabilitas dalam penelitian ini akan diproksikan dengan return on equity. Adapun rumus return on equity adalah :

return on equity $=\frac{\text { Earning After } \operatorname{Tax}(E A T)}{\text { shareholder's equity }}$

\section{Kebijakan Dividen}

Devident pay out ratio adalah proksi dari kebijakan dividen ayang akan digunakan dalam penelitian ini, adapun rumus Devident pay out ratio adalah:

$$
D P R=\frac{D P S}{E P S} \times 100 \%
$$

Sesuai dengan hipotesis, tujuan yang ingin dicapai dalam penelitian, maka digunakan model analisis jalur dengan aplikasi SPSS. (Analisis jalur merupakan suatu teknik untuk menganalisis hubungan sebab akibat yang terjadi pada regresi berganda jka variabel bebasnya mempengaruhi variabel tergantung tidak hanya secara langsung tetapi juga secara tidak langsung). Robert D. Retherford (1993) dalam Danang Sunyoto (2012:1).

Sebelum dilakukan analisis dan uji pengaruh baik secara langsung dan secara tidak langsung, akan dilakukan pengujian asumsi dasar, bahwa data harus berdistribusi normal terbebas dari Multikoliniearitas (Multicolonearity) dan Heterokedastisitas.

\section{Hasil dan Pembahasan}

Perusahaan manufaktur sub sektor food and beverages yang terdaftar di Bursa Efek Indonesia sampai dengan tahun 2014 dan sesuai dengan kriteria tertentu hanya terdapat 8 (delapan) perusahaan yang bisa dijadikan sampel penelitian.

\section{Tabel 1}

\section{Perusahaan Manufaktur yang Menjadi Sampel}

\begin{tabular}{|c|c|c|c|}
\hline No & KODE & NAMA PERUSAHAAN & $\begin{array}{l}\text { LAP. KEUANGAN YANG } \\
\text { DIGUNAKAN }\end{array}$ \\
\hline 1 & DLTA & PT. DELTA DJAKARTA, Tbk. & 31 DESEMBER $2011-2014$ \\
\hline 2 & ICBP & PT. INDOFOOD CBP SUKSES MAKMUR, Tbk. & 31 DESEMBER $2011-2014$ \\
\hline 3 & INDF & PT. INDOFOOD SUKSES MAKMUR, Tbk. & 31 DESEMBER $2011-2014$ \\
\hline 4 & MLBI & PT. MULTI BINTANG INDONESIA, Tbk. & 31 DESEMBER $2011-2014$ \\
\hline 5 & MYOR & PT. MAYORA INDONESIA, Tbk. & 31 DESEMBER $2011-2014$ \\
\hline 6 & ROTI & PT. NIPPON INDOSARI CORPORINDO, Tbk. & 31 DESEMBER 2011 - 2014 \\
\hline 7 & SKLT & PT. SEKAR LAUT, Tbk. & 31 DESEMBER $2011-2014$ \\
\hline 8 & ULTJ & PT. ULTRAJAYA MILK INDUSTRY \& TRADING, Tbk. & 31 DESEMBER $2011-2014$ \\
\hline
\end{tabular}
Penelitian 
Berdasarkan sampel yang telah terpilih, berikut ini disajikan hasil perhitungan masing-masing variabel pada 8 perusahaan manufaktur.

Tabel 2

Hasil Perhitungan Nilai Perusahaan

\begin{tabular}{|l|r|r|r|r|}
\hline \multicolumn{1}{|c|}{ NAMA PERUSAHAAN } & \multicolumn{1}{c|}{2011} & \multicolumn{1}{c|}{2012} & \multicolumn{1}{c|}{2013} & \multicolumn{1}{c|}{2014} \\
\hline PT. DELTA DJAKARTA, Tbk. & 0,225 & 0,260 & 0,199 & 0,212 \\
\hline PT. INDOFOOD CBP SUKSES MAKMUR, Tbk. & 6,025 & 9,035 & 8,607 & 8,339 \\
\hline PT. INDOFOOD SUKSES MAKMUR, Tbk. & 5,836 & 9,108 & 11,536 & 8,433 \\
\hline PT. MULTI BINTANG INDONESIA, Tbk. & 0,085 & 0,157 & 0,059 & 9,887 \\
\hline PT. MAYORA INDONESIA, Tbk. & 3,327 & 3,549 & 2,949 & 8,265 \\
\hline PT. NIPPON INDOSARI CORPINDO, Tbk. & 17,835 & 22,935 & 105,308 & 100,038 \\
\hline PT. SEKAR LAUT, Tbk. & 236,126 & 293,066 & 198,534 & 156,220 \\
\hline PT. ULTRAJAYA MILK INDUSTRY \& TRADING, Tbk. & 46,420 & 27,697 & 29,095 & 38,035 \\
\hline Sumber data-Dana Laporan Keuangan pada Bursa Efek Tndonesia diolah 2016
\end{tabular}

Tabel 3

Hasil Perhitungan

\begin{tabular}{l} 
NAMA PERUSAHAAN \\
\begin{tabular}{|l|c|c|c|c|}
\hline \multicolumn{1}{|c|}{} & 2011 & 2012 & 2013 & 2014 \\
\hline PT. DELTA DJAKARTA, Tbk. & 5,633 & 4,968 & 4,634 & 4,339 \\
\hline PT. INDOFOOD CBP SUKSES MAKMUR, Tbk. & 2,826 & 2,704 & 2,346 & 2,107 \\
\hline PT. INDOFOOD SUKSES MAKMUR, Tbk. & 1,857 & 1,978 & 1,586 & 0,124 \\
\hline PT. MULTI BINTANG INDONESIA, Tbk. & 0,939 & 0,489 & 0,876 & 0,475 \\
\hline PT. MAYORA INDONESIA, Tbk. & 1,825 & 2,541 & 2,290 & 1,850 \\
\hline PT. NIPPON INDOSARI CORPINDO, Tbk. & 1,136 & 1,008 & 1,002 & 1,355 \\
\hline PT. SEKAR LAUT, Tbk. & 1,709 & 1,361 & 1,221 & 1,150 \\
\hline PT. ULTRAJAYA MILK INDUSTRY \& TRADING, Tbk. & 1,449 & 1,989 & 2,412 & 3,282 \\
\hline
\end{tabular} \\
Sumber data: Data Laporan Keuangan pada Bursa Efek Indonesia diolah 2016 \\
\hline
\end{tabular}

Tabel 4

Hasil Perhitungan Leverage

\begin{tabular}{|l|r|r|r|r|}
\hline \multicolumn{1}{|c|}{ NAMA PERUSAHAAN } & \multicolumn{1}{c|}{2011} & \multicolumn{1}{c|}{2012} & \multicolumn{1}{c|}{2013} & \multicolumn{1}{c|}{2014} \\
\hline PT. DELTA DJAKARTA, Tbk. & 7,696 & 9,186 & 11,895 & 14,205 \\
\hline PT. INDOFOOD CBP SUKSES MAKMUR, Tbk. & 7,740 & 9,890 & 13,723 & 16,927 \\
\hline PT. INDOFOOD SUKSES MAKMUR, Tbk. & 25,028 & 28,756 & 45,237 & 50,921 \\
\hline PT. MULTI BINTANG INDONESIA, Tbk. & 32,774 & 39,022 & 37,713 & 79,604 \\
\hline PT. MAYORA INDONESIA, Tbk. & 10,893 & 13,657 & 13,007 & 13,844 \\
\hline PT. NIPPON INDOSARI CORPINDO, Tbk. & 2,101 & 5,318 & 10,227 & 11,683 \\
\hline PT. SEKAR LAUT, Tbk. & 1,322 & 1,741 & 2,350 & 2,580 \\
\hline PT. ULTRAJAYA MILK INDUSTRY \& TRADING, Tbk. & 1,434 & 1,288 & 1,379 & 1,129 \\
\hline
\end{tabular}

Tabel 5

\section{Hasil Perhitungan Profitabilitas}

\begin{tabular}{|c|c|c|c|c|}
\hline NAMA PERUSAHAAN & 2011 & 2012 & 2013 & 2014 \\
\hline PT. DELTA DJAKARTA, Tbk. & 0,265 & 0,357 & 0,400 & 0,377 \\
\hline PT. INDOFOOD CBP SUKSES MAKMUR, Tbk. & 0,193 & 0,190 & 0,168 & 0,168 \\
\hline PT. INDOFOOD SUKSES MAKMUR, Tbk. & 0,155 & 0,185 & 0,089 & 0,107 \\
\hline PT. MULTI BINTANG INDONESIA, Tbk. & 0,957 & 1,375 & 1,186 & 1,435 \\
\hline PT. MAYORA INDONESIA, Tbk. & 0,199 & 0,090 & 0,260 & 0,100 \\
\hline PT. NIPPON INDOSARI CORPINDO, Tbk. & 0,212 & 0,224 & 0,201 & 0,263 \\
\hline PT. SEKAR LAUT, Tbk. & 0,049 & 0,061 & 0,082 & 0,107 \\
\hline PT. ULTRAJAYA MILK INDUSTRY \& TRADING, Tbk. & 0,095 & 0,211 & 0,161 & 0,125 \\
\hline
\end{tabular}

Tabel 6

Hasil Perhitungan Kebijakan Dividen

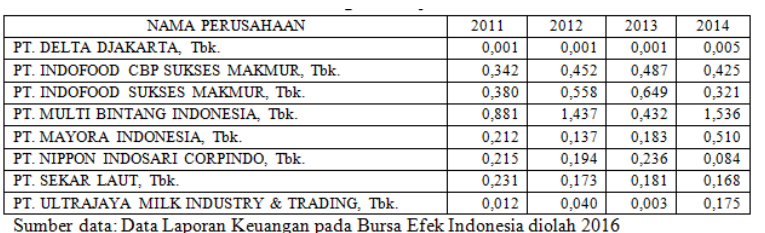

Sumber data: Data Laporan Keuangan pada Bursa Efek Indonesia diolah 2016

\section{Hasil Pengujian Asumsi Klasik Hasil Uji Normalitas}

Pengujian normalitas dilakukan terhadap residual regresi. Pengujian dilakukan dengan menggunakan grafik P-P Plot. Hasil pengujian normalitas data menunjukkan adanya pola grafik yang normal dimana titik-titik berada tidak jauh dari garis diagonal, hal ini berarti bahwa model regresi tersebut sudah berdistribusi normal.

\section{Hasil Uji Multikolinieritas}

Suatu variabel menunjukkan gejala multikolinieritas bisa dilihat dari nilai VIF (Variance Inflation Factor) yang tinggi pada variabel-variabel bebas suatu model regresi. Hasil pengujian menunjukkan bahwa semua variabel yang digunakan sebagai prediktor model regresi menunjukkan nilai VIF yang cukup kecil, dimana semuanya berada di bawah 10 dan nilai tollerance lebih dari 0,1 . Hal ini berarti bahwa variabel bebas yang digunakan dalam penelitian tidak menunjukkan adanya gejala multikolinieritas.

\section{Hasil Uji Heteroskedastisitas}

Pengujian heteroskedastisitas dilakukan dengan menggunakan Scatter Plot. Hasil pengujian heteroskedastisitas menunjukkan tidak terdapat pola yang jelas dari titik-titik tersebut. Hal ini menunjukkan bahwa model regresi tidak memiliki gejala adanya heteroskedastisitas, yang berarti bahwa tidak ada gangguan yang berarti dalam model regresi ini.

\section{Hasil Pengujian Hipotesis \\ Hasil Uji Subtruktur Pertama}

Pengujian substruktur pertama dilakukan dengan menguji pengaruh variabel independen yaitu likuiditas (current ratio) (X1), leverage (debt to equity ratio) (X2), dan profitabilitas (return on equity) (X3), terhadap kebijakan dividen (Y1). Pengujian substruktur pertama menghasilkan diagram jalur sebagai berikut sebagai berikut: 


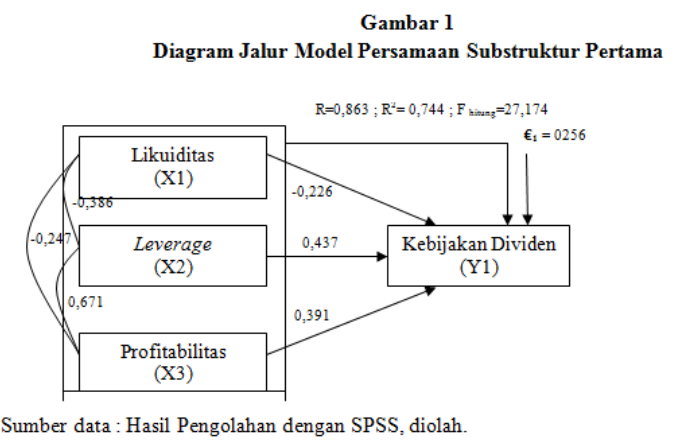

Keterangan: $€_{1}=1$ - R square

$$
\begin{aligned}
& =1-0,744 \\
& =0,256
\end{aligned}
$$

Model persamaan yang dihasilkan dari pengujian substruktur pertama sebagai berikut:

$Y_{1}=-0,226 X_{1}+0,437 X_{2}+0,391 X_{3}+0,256$

Sedangkan secara simultan diperoleh hasil sebagai berikut:

1) Pengaruh variabel independen likuiditas (current ratio) (X1), leverage (debt to equity ratio) (X2), dan profitabilitas (return on equity) (X3) terhadap kebijakan dividen (Y) ditunjukkan oleh nilai $\mathrm{F}$ hitung $(27,174)>\mathrm{F}$ tabel $(2,95)$ dengan tingkat signifikansi 0,000 berarti terdapat pengaruh likuiditas (current ratio), leverage (debt to equity ratio), dan profitabilitas (return on equity) yang signifikan secara simultan terhadap kebijakan dividen.

2) Nilai $R$ square $\left(R^{2}\right)$ sebesar 0,744 menunjukkan bahwa kebijakan dividen dipengaruhi oleh likuiditas (current ratio), leverage (debt to equity ratio), dan profitabilitas (return on equity) sebesar $74,4 \%$ sedangkan sisanya yang ditunjukkan oleh nilai $€_{1}$ sebesar $25,6 \%$ menunjukkan bahwa kebijakan dividen dipengaruhi oleh variabel lainnya.

3) Untuk mengetahui apakah model regresi sudah tepat atau tidak, maka diperlukan uji hipotesis dengan menggunakan uji $F$ atau dengan membandingkan besarnya taraf signifikan pada tabel ANOVA.

Jika signifikansi hitung > 0,05 maka model regresi dikatakan tidak layak.

Jika signifikansi hitung $<0,05$ maka model regresi dikatakan layak.

Berdasarkan perhitungan angka signifikansi sebesar $0,000<0,05$ maka model regresi yang diperoleh dari pengujian substruktur pertama ini sudah layak dan benar.
Hasil analisis atas model subtruktur pertama menghasilkan korelasi antar variabel independen sebagai berikut:

1) Korelasi antara likuiditas (current ratio) (X1) dengan leverage (debt to equity ratio) (X2) sebesar -0,386 artinya hubungan kedua variabel cukup dan berlawanan arah dimana jika likuiditas (current ratio) tinggi maka leverage (debt to equity ratio) rendah dan sebaliknya.

2) Korelasi antara likuiditas (current ratio) (X1) dengan profitabilitas (return on equity) (X3) sebesar - 0,247 artinya hubungan kedua variabel sangat lemah dan berlawanan arah dimana jika likuiditas (current ratio) tinggi maka profitabilitas (return on equity) rendah dan sebaliknya.

3) Korelasi antara leverage (debt to equity ratio) (X2) dengan profitabilitas (return on equity) (X3) sebesar 0,671 artinya hubungan kedua variabel kuat dan searah dimana jika leverage (debt to equity ratio) tinggi maka profitabilitas (return on equity) juga tinggi dan sebaliknya.

4) Nilai koefisien korelasi berganda $\left(R^{2}\right)$ sebesar 0,744 menunjukkan korelasi yang tinggi antara variabel independen likuiditas (current ratio) (X1), leverage (debt to equity ratio) (X2), dan profitabilitas (return on equity) (X3) dengan kebijakan dividen $(\mathrm{Y})$.

Semua korelasi tersebut menunjukkan hubungan yang signifikan karena tingkat signifikansinya $=0,00$ atau $<0,05$.

\section{Hasil Uji Substruktur Kedua}

Pengujian substruktur kedua dilakukan dengan menguji pengaruh variabel independen yaitu likuiditas (current ratio) (X1), leverage (debt to equity ratio) (X2), dan profitabilitas (return on equity) (X3) terhadap nilai perusahaan (Y2) dengan melalui variabel kebijakan dividen (Y1). Pengujian substruktur kedua menghasilkan diagram jalur sebagai berikut sebagai berikut: 


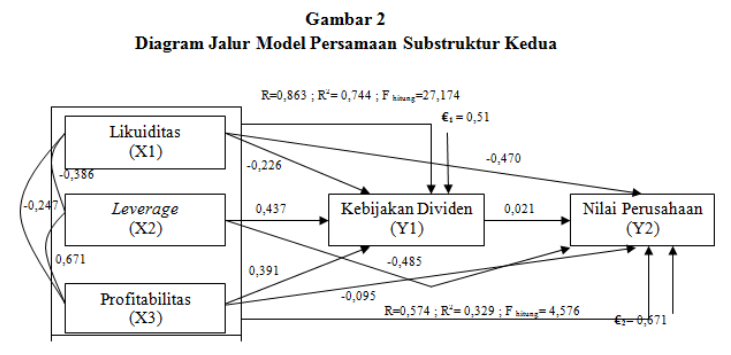

Sumber data : Hasil Pengolahan dengan SPSS, diolah.

Keterangan: $€_{2}=1$ - R square

$$
\begin{aligned}
& =1-0,329 \\
& =0,671
\end{aligned}
$$

Model persamaan yang dihasilkan dari pengujian substruktur kedua sebagai berikut:

$\mathrm{Y}_{2}=-0,470 \mathrm{X}_{1}-0,485 \mathrm{X}_{2}-0,095 \mathrm{X}_{3}+0,671$

Untuk mengetahui apakah model regresi sudah tepat atau tidak, maka diperlukan uji hipotesis dengan menggunakan uji $\mathrm{F}$ atau dengan membandingkan besarnya taraf signifikan pada tabel ANOVA.

\section{Pengujian Hipotesis \\ Pengujian Hipotesis 1}

Pengujian hipotesis secara parsial atau individu untuk masing-masing variabel melalui pengujian model substruktur kedua sebagai berikut:

Pengaruh likuiditas (current ratio) (X1) terhadap nilai perusahaan (Y2)

Diperoleh nilai t hitung sebesar -2,801 dengan tingkat signifikan $0,009 \quad$ berarti $-\mathrm{t}_{\text {hitung }}(-2,801)<-\mathrm{t}_{\text {tabel }}(-2,042)$ dan sig $(0,009)$ $<\alpha(0,05)$ maka hipotesis diterima dan disimpulkan bahwa likuiditas (current ratio) (X1) berpengaruh signifikan terhadap nilai perusahaan (Y2).

Pengaruh leverage (debt to equity ratio) (X2) terhadap nilai perusahaan (Y2)

Diperoleh nilai $\mathrm{t}$ hitung sebesar -2,210 dengan tingkat signifikan $0,035 \quad$ berarti $-\mathrm{t}_{\text {hitung }}(-2,210)<-\mathrm{t}$ tabel $(-2,042)$ dan sig $(0,035)$ $<\alpha(0,05)$ maka hipotesis diterima dan disimpulkan bahwa leverage (debt to equity ratio) berpengaruh signifikan terhadap nilai perusahaan (Y2).

Pengaruh profitabilitas (return on equity) (X3) terhadap nilai perusahaan (Y2)

Diperoleh nilai t hitung sebesar -,455 dengan tingkat signifikan 0,653 berarti $-\mathrm{t}$ hitung $(-0,455)>-\mathrm{t}$ tabel $(-2,042)$ dan $-\mathrm{t}$ hitung $(-$ $0,455)<\mathrm{t}_{\text {tabel }}(2,042)$ dan sig $(0,653)>\alpha(0,05)$ maka hipotesis diteolak dan disimpulkan profitabilitas (return on equity) (X3) tidak berpengaruh signifikan terhadap nilai perusahaan (Y2).

Pengujian Hipotesis 2

Dari hasil pengujian diperoleh nilai $F$ hitung sebesar 4,576 dengan tingkat signifikan 0,010 berarti $\mathrm{F}_{\text {hitung }}(4,576)>\mathrm{F}_{\text {tabel }}(2,95)$ dan $\operatorname{sig}(0,010)<\alpha$ $(0,05)$ maka hipotesis diterima dan disimpulkan terdapat pengaruh likuiditas, leverage, profitabilitas yang signifikan secara simultan terhadap nilai perusahaan manufaktur di Indonesia.

Pengujian Hipotesis 3

Dari hasil pengujian diperoleh nilai $\mathrm{F}$ hitung sebesar 3,311 dengan tingkat signifikan 0,025 berarti $F_{\text {hitung }}(3,311)>F_{\text {tabel }}(2,95)$ dan $\operatorname{sig}(0,020)<\alpha$ $(0,05)$ maka hipotesis diterima dan disimpulkan terdapat pengaruh yang signifikan secara simultan melalui variabel kebijakan dividen terhadap nilai perusahaan manufaktur di Indonesia.

\section{Pengujian Hipotesis 4}

Dari hasil pengujian diketahui korelasi atau hubungan antara likuiditas, leverage, profitabilitas secara parsial terhadap nilai perusahaan manufaktur di Indonesia sebagai berikut:

1) Nilai korelasi antara likuiditas (X1) dengan nilai perusahaan (Y2) sebesar $-0,260$ dengan signifikansi 0,151 berarti terdapat hubungan yang tidak signifikan.

2) Nilai korelasi antara leverage (X2) dengan nilai perusahaan (Y2) sebesar -0,367 dengan signifikansi 0,039 berarti terdapat hubungan yang sangat signifikan dengan kriteria cukup dan tidak searah artinya jika leverage (X2) tinggi maka nilai perusahaan (Y2) menurun dan sebaliknya.

3) Nilai korelasi antara profitabilitas (X3) dengan nilai perusahaan (Y2) sebesar -0,304 dengan signifikansi 0,090 berarti terdapat hubungan yang tidak signifikan.

\section{Pengujian Hipotesis 5}

Berdasarkan output pengujian likuiditas, leverage, profitabilitas terhadap nilai perusahaan diperoleh nilai koefisien korelasi berganda (R) sebesar 0,574 dengan signifikansi 0,010 yang berarti terbukti terdapat hubungan dengan kriteria kuat positif dan sangat signifikan. Sedangkan nilai koefisien determinasi ( $\mathrm{R}$ square) sebesar 0,329 atau 
$32,9 \%$ yang artinya variabel likuiditas, leverage, profitabilitas mampu menjelaskan pengaruhnya terhadap perubahan variabel nilai perusahaan manufaktur di Indonesia secara bersama-sama sebesar $32,9 \%$ dan sisanya $67,1 \%$ dijelaskan oleh variabel lainnya.

\section{Pengujian Hipotesis 6}

Diketahui bahwa korelasi antara kebijakan (Y1) dengan nilai perusahaan (Y2) sebesar 0,021 dan signifikansi 0,946 berarti terdapat hubungan dan tidak signifikan. Jadi terbukti terdapat hubungan antara kebijakan yang tidak signifikan terhadap nilai perusahaan manufaktur di Indonesia.

\section{Pembahasan Hasil Penelitian Pembahasan Hasil Pengujian Hipotesis Pertama}

Pembahasan ini berkaitan dengan hasil pengujian terhadap hipotesis pertama yang menyatakan bahwa terdapat pengaruh likuiditas, leverage, profitabilitas yang signifikan secara parsial terhadap nilai perusahaan manufaktur di Indonesia. Hasil penelitian menunjukkan bahwa yang berpengaruh signifikan terhadap nilai perusahaan adalah likuiditas dan leverage. Sedangkan profitabilitas tidak berpengaruh terhadap nilai perusahaan.

Berdasarkan uraian di atas, maka pengujian hipotesis pertama dapat diterima untuk 2 (dua) variabel yang berpengaruh signifikan yaitu likuiditas dan leverage, sedangakan 1 (satu) variabel lainnya yaitu profitabilitas tidak berpengaruh signifikan terhadap nilai perusahaan.

\section{Pembahasan Hasil Pengujian Hipotesis Kedua}

Pembahasan ini berkaitan dengan hasil pengujian terhadap hipotesis kedua yang menyatakan bahwa terdapat pengaruh likuiditas, leverage, profitabilitas yang signifikan secara simultan terhadap nilai perusahaan manufaktur di Indonesia. Hasil penelitian menunjukkan bahwa secara simultan atau bersama-sama variabel independen yang terdiri dari likuiditas, leverage, profitabilitas berpengaruh signifikan terhadap nilai perusahaan.

\section{Pembahasan Hasil Pengujian Hipotesis Ketiga}

Pembahasan ini berkaitan dengan hasil pengujian terhadap hipotesis ketiga yang menyatakan bahwa terdapat pengaruh likuiditas, leverage, profitabilitas yang signifikan secara simultan melalui variabel kebijakan dividen terhadap nilai perusahaan manufaktur di Indonesia. Hasil penelitian menunjukkan bahwa terdapat pengaruh likuiditas, leverage, profitabilitas yang signifikan secara simultan terhadap loyalitas nasabah melalui variabel kebijakan dividen. Besarnya pengaruh likuiditas, leverage, profitabilitas terhadap nilai perusahaan melalui kebijakan dividen secara parsial dibandingkan secara simultan ternyata memberikan hasil pengaruh lebih kecil jika secara simultan dan melalui kebijakan dividen. Pengaruh langsung kebijakan dividen terhadap nilai perusahaan memberikan hasil paling kecil, jadi dapat disimpulkan bahwa untuk mencapai nilai perusahaan maka tidak perlu memperhatikan kebijakan dividen.

\section{Pembahasan Hasil Pengujian Hipotesis Keempat}

Pembahasan ini berkaitan dengan hasil pengujian terhadap hipotesis keempat yang menyatakan bahwa terdapat hubungan likuiditas, leverage, profitabilitas yang signifikan secara parsial terhadap nilai perusahaan manufaktur di Indonesia. Hasil penelitian menunjukkan bahwa secara parsial hanya leverage yang mempunyai hubungan yang cukup kuat dan tidak searah terhadap nilai perusahaan, sedangkan likuiditas dan profitabilitas memiliki hubungan yang tidak searah dan tidak signifikan terhadap nilai perusahaan.

\section{Pembahasan Hasil Pengujian Hipotesis Kelima} Pembahasan ini berkaitan dengan hasil pengujian terhadap hipotesis kelima yang menyatakan bahwa terdapat hubungan likuiditas, leverage, profitabilitas yang signifikan secara simultan terhadap nilai perusahaan manufaktur di Indonesia. Hasil pengujian likuiditas, leverage, profitabilitas terhadap nilai perusahaan diperoleh nilai koefisien korelasi berganda $(\mathrm{R})$ sebesar 0,574 dengan signifikansi 0,010 yang berarti terbuti terdapat hubungan dengan kriteria kuat positif dan sangat signifikan. Sedangkan nilai koefisien determinasi ( $\mathrm{R}$ square) sebesar 0,329 atau $32,9 \%$ yang artinya variabel likuiditas, leverage, profitabilitas mampu menjelaskan pengaruhnya terhadap perubahan variabel nilai perusahaan secara bersama-sama sebesar $32,9 \%$ dan sisanya $67,1 \%$ dijelaskan oleh variabel lainnya. 
Pembahasan Hasil Pengujian Hipotesis Keenam

Pembahasan ini berkaitan dengan hasil pengujian terhadap hipotesis keenam yang menyatakan bahwa terdapat hubungan antara kebijakan dividen yang signifikan terhadap nilai perusahaan manufaktur di Indonesia. Hasil pengujian menunjukkan bahwa korelasi antara kebijakan dividen (Y1) dengan nilai perusahaan (Y2) sebesar 0,215 dan signifikansi 0,236 berarti kriteria hubungan keduanya termasuk dalam kategori sangat lemah dan tidak signifikan. Jadi terbukti terdapat hubungan antara kebijakan dividen yang tidak signifikan terhadap nilai perusahaan manufaktur di Indonesia.

Sesuai dengan konsep kebijakan dividen yang beranggapan bahwa Dividen tidak relevan (the irrelevant of Dividend). Modigliani dan Miller (1958) mengatakan bahwa (kebijakan Dividen tidak mempunyai pengaruh terhadap harga saham perusahaan). Nilai perusahaan hanya ditentukan oleh kemampuan menghasilkan laba, bukan pada pembagian laba perusahaan untuk dividen atau sebagai laba ditahan.

\section{Simpulan}

Berdasarkan hasil penelitian dan pembahasan yang telah diuraikan di atas, maka dapat diambil beberapa kesimpulan sebagai berikut :

a. Hasil pengujian terhadap hipotesis pertama menunjukkan bahwa yang berpengaruh signifikan terhadap nilai perusahaan adalah likuiditas dan leverage. Sedangkan profitabilitas tidak berpengaruh terhadap nilai perusahaan.

b. Hasil pengujian terhadap hipotesis kedua menunjukkan bahwa secara simultan atau bersama-sama variabel independen yang terdiri dari likuiditas, leverage, profitabilitas berpengaruh signifikan terhadap nilai perusahaan.

c. Hasil pengujian terhadap hipotesis ketiga menunjukkan bahwa terdapat pengaruh likuiditas, leverage, profitabilitas yang signifikan secara simultan terhadap nilai perusahaan melalui variabel kebijakan dividen.

d. Hasil pengujian terhadap hipotesis keempat menunjukkan bahwa secara parsial hanya leverage yang mempunyai hubungan yang cukup kuat dan tidak searah terhadap nilai perusahaan, sedangkan likuiditas dan profitabilitas memiliki hubungan yang tidak searah dan tidak signifikan terhadap nilai perusahaan.

e. Hasil pengujian terhadap hipotesis kelima menunjukkan terdapat hubungan dengan kriteria kuat positif dan sangat signifikan.

f. Hasil pengujian terhadap hipotesis keenam menunjukkan terdapat hubungan antara kebijakan dividen yang tidak signifikan terhadap nilai perusahaan manufaktur di Indonesia.

\section{Daftar Pustaka}

[1] Alfredo Mahendra DJ, 2011, Pengaruh Kinerja Keuangan Terhadap Nilai Perusahaan (Kebijakan Dividen Sebagai Variabel Moderating) Pada Perusahaan Manufaktur Di Bursa Efek Indonesia, Thesis, Program Studi Manajemen, Program Pascasarjana, Universitas Udayana, Denpasar.

[2] Arikunto. 2003. Manajemen Penelitian. Jakarta.Renika Cipta.

[3] Brigham, Eugene F. and Joel F. Houston, 2001. Fundamentals of Financial Management, Ninth

[4] Chen, C. K. (2004). Research on impacts of team leadership on team effectiveness.The Journal of American Academy of Business, Cambridge, 266-278.

[5] Fakhruddin, M. dan M.S. Hadianto. 2001. Perangkat dan Model Analisis Investasi di PasarModal. Jakarta. Elex Media Komputindo.

[6] Harjito, A dan Martono. 2005. Manajemen Keuangan. Yogyakarta.

[7] Horne \& Wachowicz, 2005, Prinsip-Prinsip Manajemen Keuangan, Jakarta. Salemba Empat,

[8] http://finance.yahoo.com/q/hp?s=CPIN.JK\&a $=00 \& \mathrm{~b}=1 \& \mathrm{c}=2011 \& \mathrm{~d}=11 \& \mathrm{e}=31 \& \mathrm{f}=2014 \& \mathrm{~g}$ $=\mathrm{m}$

[9] Husnan, Suad (2001). Manajemen Keuangan Teori Dan Penerapan (Keputusan Jangka Pendek) Buku 2 Edisi 4 Cetakan Pertama. Yogyakarta. BPFE.

[10] Jogiyanto. 2011. Structural Equation Modeling. Yogyakarta. STIM YKPN. 
[11] Jogiyanto. 2011. Metodologi Penelitian Bisnis. Yogyakarta. BPFE.

[12] Kusumadilaga, Rimba. 2010. Pengaruh Corporate Social Responsibility Terhadap Nilai Perusahaan dengan Profitabilitas Sebagai Variabel Moderating, Skripsi, Fakultas Ekonomi Diponegoro Semarang.

[13] Morenly Welley \& Victoria Untu, 2015, Faktor-Faktor yang Mempengaruhi Nilai Perusahaan di Sektor Pertanian Pada Bursa Efek Indonesia Tahun 2010 - 2013

[14] Napa J, Awat. 1999. Manajemen Keuangan : Pendekatan Sistematis. Jakarta. PT Gramedia Pustaka Utama.

[15] Nugroho. Anton. dan Yohanes. 2011. It's Easy Olah Data Dengan SPSS. Yogyakarta. Skripta Media Creative.

[16] Nurlela dan Islahuddin. 2008. Pengaruh Corporate Social Responsibility terhadap Nilai Peusahaan dengan Prosentase Kepemilikan Manajemen sebagai Variabel Moderating. Simposium Nasional Akuntansi $X I$

[17] Pancawati Hardiningsih, 2009, Determinan Nilai Perusahaan, JAI Vol. 5 No. 2 Juli 2009: 231-250, Universitas STIKUBANK, Semarang

[18] Pinuji, Ponco Satriyo. 2009. Pengaruh Rasio Keuangan terhadap Harga Sahampada Perusahaan Manufaktur di Bursa Efek Indonesia (BEI) Periode 20052007.Skripsi. Fakultas Ekonomi Universitas Muhammadiyah Surakarta.

[19] Prayitno, Anggia. 2008. Pengaruh Profitabilitas, Solvabilitas, dan Likuiditas Terhadap Harga Saham Sektor Properti di Bursa Efek Jakarta Tahun 2001-2006, Skripsi, Universitas Widyatama.

[20] Rika Susanti (2010) dengan judul "Analisis Faktor-Faktor yang Berpengaruh Terhadap Nilai Perusahaan (studi kasus pada perusahaan go publik yang listed di BEI periode 2005 2008)

[21] Riyanto, Bambang. 2001. Dasar-dasar pembelanjaan Perusahaan. Yogyakarta: BPFE. Winardi. 2001. Ekonomi Majerial. Bandung . Mandar Maju.

[22] Sri Hasnawati \& Agnes Sawir, 2015, Keputusan Keuangan, Ukuran Perusahaan,
Struktur Kepemilikan dan Nilai Perusahaan Republik Indonesia, JMK, Vol. 17 No. 1 Maret 2015

[23] Sri Hermuningsih, 2013, Pengaruh Profitabilitas, Growth Opportunity, Sruktur Modal Terhadap Nilai Perusahaan Pada Perusahaan Publik Di Indonesia, Buletin Ekonomi Moneter dan Perbankan, Oktober 2013.

[24] Soliha, E. dan Taswan. 2002. Pengaruh Kebijakan Hutang terhadap Nilai Perusahaan serta Beberapa Faktor yang Mempengaruhinya. Jurnal Bisnis dan Ekonomi. Vol. 9. No. 2.September: 149-163.

[25] Sujoko, \& Soebiantoro, U. (2007). Pengaruh strukturkepemilikan saham, leverage, faktor intern dan faktor ekstern terhadap nilai perusahaan. Jurnal Manajemen dan Kewirausahaan. 9(1), 41-48.

[26] Sunariyah. 2004. Pengantar Pengetahuan Pasar Modal Edisi Keempat. Yogyakarta. UPP AMP YKPN.

[27] Tri Wahyuni, Endang Ernawati, dan Werner R. Murhadi (2014) dengan judul "FaktorFaktor Yang Mempengaruhi Nilai Perusahaan di Sektor Property, Real Estate \& Bulding Construction

[28] Wahyudi, Untung; Pawestri, Hartini Prasetyaning. 2006. Implikasi Struktur Kepemilikan Terhadap Nilai Perusahaan dengan Keputusan Keuangan Sebagai Variabel Intervening. Simposium Nasional Akuntansi (SNA) IX, Padang, 23-26 Agustus 2006.

[29] Yuliana, dkk (2013) dengan judul “ Pengaruh Struktur Modal dan Return On Equity (ROE) Terhadap Nilai Perusahaan Pada Perusahaan Sektor Pertanian Di Bursa Efek Indonesia 